\title{
Work Addiction is not New to the Psychological Literature and has Evolved over Time
}

\author{
Paweł A Atroszko ${ }^{1}$ and Mark D Griffiths ${ }^{2^{*}}$ \\ ${ }^{1}$ Adjunct Professor, Department of Psychometrics and Statistics, Institute of Psychology, University of Gdańsk Poland \\ ${ }^{2}$ Distinguished Professor of Behavioural Addiction, Psychology Department, Nottingham Trent University, 50 Shakespeare Street, Nottingham, NG1 4FQ, \\ UK
}

Submission: August 22, 2017; Published: August 29, 2017

*Corresponding author: Mark D Griffiths, Distinguished Professor of Behavioural Addiction, Psychology Department, Nottingham Trent University, 50 Shakespeare Street, Nottingham, NG1 4FQ, UK, Email: mark.griffiths@ntu.ac.k

\section{Opinion}

In a recent edition of the journal Addiction, Kardefelt-Winther et al. [1] drew attention to the conceptualization and assessment of behavioural addiction and argued that it may lead to pathologizing of common activities. One such example provided by the authors was work addiction. Consequently, readers might have been left with the impression that work addiction is a newly developed concept. However, this is not the case. The occurrence of psychosomatic symptoms on days where individuals were unable to work can be traced back to 1919 [2], while the formal notion of work addiction entered the psychological literature almost 50 years ago following the publication of Oates' seminal book, Confessions of a Workaholic [3] with a large increase in papers on the disorder over the last 30 years [4]. Consequently, work addiction is not a recently identified problem. Furthermore, work addiction also fits well into Kardefelt-Winther et al.'s [1] conceptualization of a behavioural addiction. More specifically, three principal observations are worth noting.

Firstly, there has been a relatively long period of a personcentred approach to research, from the initial recognition of a potential disorder comprising case studies and qualitative studies. These studies explored the phenomenology of the work addiction, identifying its aetiology and course [3,5] and proposed theories based on family dysfunction and personality predispositions, as well as models based on learning theory, cognitive theories, and addiction theory [5-7]. Therefore, in the initial stage of the concept development the problem was not atheoretical. On the contrary, there was a plethora of theories but they lacked integration of the findings and frameworks. Secondly, assessment instruments have been developed and evaluated in terms of their psychometric properties [4-8]. This has led to scales [9] being developed based on common addiction components [10] resulting in a slowly emerging consensus defining work addiction as a behavioural addiction rather than a form of positive high engagement [4-7,11,12].

What follows is the postulate that good theory articulates not only what a construct is, but also what it is not. The process of clarifying conceptualisations of work addiction took decades of empirical research in many countries comprising both eastern and western cultures $[4,6-7,11,12]$. There is now agreement among researchers about differences between passionate work engagement and work addiction [4-7,1115]. Although research shows comorbidity of work addiction with other psychopathologies [16], work addiction has its own phenomenology and aetiology, congruent with other addictions [17].

Finally, the criteria of the persistence of the disorder and of long-term impairment due to harm and distress were suggested by Kardefelt-Winther et al. as crucial for recognizing behaviour as addictive. Two sources of evidence for fulfilment of both of these criteria should be taken into account when it comes to work addiction. Firstly, the large number of case studies and clinical observations, and qualitative research data [3,5], and secondly, longitudinal empirical studies $[14,15,18,19]$ showing that it is not a transient behavioural pattern and leads to significant impairment [3-7,11,13]. Additionally, Workaholics Anonymous groups have operated in several countries internationally for more than 30 years [5]. These groups demonstrate there are people who seek help because they recognize persistent problems that significantly impair their functioning. Admittedly, some researchers draw attention to the cultural renunciation and often ridicule of the concept of work addiction in mass media [5]. However, it is necessary to acknowledge that the disowning of the construct by society might be a problem inherent to workaholism research, and conceivably this reluctance to widely acknowledge the matter should itself be systematically studied. 
Research on work addiction is beyond the phase of 'proof of concept' and research has shown that for a minority of individuals there is evidence of compulsive repeated overinvolvement in work, persisting over a long time, different from passion or healthy high engagement, and related to long-term impairment due to harm and distress. Taking this into account, it seems worthwhile to suggest that the field would greatly benefit from an open discussion and integration of knowledge about work addiction studied within the addiction framework. This could include developing more consensus about what is already known about workaholism as well as delineating the crucial directions for immediate and long-term future research. Such discussions may stimulate and/or facilitate a more dynamic development of the field, parallel to the one observed in other domains of behavioural addictions, such as internet gaming addiction [20], which has significantly shorter history of research than work addiction.

\section{References}

1. Kardefelt-Winther D, Heeren A, Schimmenti A, van Rooij A, Maurage P, et al. (2017) How can we conceptualize behavioral addiction without pathologizing common behaviors? Addiction in press.

2. Ferenczi S (1919) II Sonntagsneurosen. Internationale Zeitschriftfür Psychoanalyse 5: 46-48.

3. Oates W (1971) Confessions of a Workaholic. World Books, New York, NY, USA.

4. Sussman S (2012) Workaholism: A review. J AddictRes Therapy, Suppl 6: 4120 .

5. Robinson BE (2014) Chained to the desk: A guidebook for workaholics, their partners and children, and the clinicians who treat them. NYU Press, New York, NY, USA.

6. Quinones C, Griffiths MD (2015) Addiction to work: A critical review of the workaholism construct and recommendations for assessment. J Psychosocial Nurs Mental Health Services 53: 48-59.

7. Andreassen CS (2013) Workaholism: An overview and current status of the research. J Behav Addict 3: 1-11.

8. Machlowitz M (1980) Workaholics: Living with them, working with them. Addison-Wesley, Reading, MA, USA.

9. Andreassen CS, Griffiths MD, HetlandJ, PallesenS (2012) Development of a work addiction scale. Scand J Psychol 53: 265-272.

10. Griffiths MD (2005) Components' model of addiction within a biopsychosocial framework. J Subst Use10: 191-197.

11. Clark MA, Michel JS, Zhdanova L, Pui SY, Baltes BB (2016) All work and no play? A meta-analytic examination of the correlates and outcomes of workaholism. J Management 42: 1836-1873.

12. Taris TW, Schaufeli WB, Shimazu A (2010) The push and pull of work: About the difference between workaholism and work engagement. In: Bakker AB, Leiter MP (eds.), Work engagement: A handbook of essential theory and research, Psychology Press, London, UK, pp. 3953.

13. Griffiths MD, Karanika-Murray M (2012) Contextualising overengagement in work: Towards a more global understanding of workaholism as an addiction. J BehavAddict 1: 87-95.

14. Shimazu A, Schaufeli WB, Kamiyama K, Kawakami N(2015) Workaholism vs. work engagement: the two different predictors of future well-being and performance. Int J Behav Med 22: 18-23.

15. Hakanen J, Peeters M (2015) How do work engagement, workaholism, and the work-to-family interface affect each other? A 7-year follow-up study. J Occ Env Med 57: 601-609.

16. Andreassen CS, Griffiths MD, Sinha R, Hetland J, Pallesen S (2016) The relationships between workaholism and symptoms of psychiatric disorders: A large-scale cross-sectional study. PloSONE 11: e0152978.

17. Fatséas M, Hurmic H, Serre F, Debrabant R, Daulouède JP, et al. (2016) Addiction severity pattern associated with adult and childhood Attention Deficit Hyperactivity Disorder (ADHD) in patients with addictions. Psychiatry Res 246: 656-662.

18. Andreassen CS, Bjorvatn B, Moen BE, Waage S, Magerøy N, et al. (2016) A longitudinal study of the relationship between the five-factor model of personality and workaholism. TPM: Testing, Psychometrics, Methodol Appl Psychol 23: 285-298.

19. Atroszko PA, Andreassen CS, Griffiths MD, Pallesen S (2016) The relationship between study addiction and work addiction: A crosscultural longitudinal study. J Behav Addict 5: 708-714.

20. Kuss DJ, Griffiths, MD, Pontes, HM (2017) Chaos and confusion in DSM-5 diagnosis of Internet Gaming Disorder: Issues, concerns, and recommendations for clarity in the field. J Behav Addict 6: 103-109.

\section{Your next submission with Juniper Publishers will reach you the below assets}

- Quality Editorial service

- Swift Peer Review

- Reprints availability

- E-prints Service

- Manuscript Podcast for convenient understanding

- Global attainment for your research

- Manuscript accessibility in different formats

( Pdf, E-pub, Full Text, Audio)

- Unceasing customer service

Track the below URL for one-step submission https://juniperpublishers.com/online-submission.php 